\title{
BEING MINORITY IN PAPUA: Religious and Political Identity Struggle of the Dani Muslims
}

\author{
Ade Yamin \\ Universitas Muhammadiyah Yogyakarta \\ E-mail: yaminpapua79@yahoo.com \\ Irwan Abdullah \\ Universitas Gadjah Mada \\ E-mail: irwanabdullah6@gmail.com \\ Achmad Nurmandi \\ Universitas Muhammadiyah Yogyakarta \\ E-mail: nurmandi_achmad@umy.ac.id \\ Hasse Jubba \\ Universitas Muhammadiyah Yogyakarta \\ E-mail: hasse@umy.ac.id \\ Zuli Qodir \\ Universitas Muhammadiyah Yogyakarta \\ E-mail: zuly_qodir@yahoo.com
}

\begin{abstract}
The issue of religious and political identity of the Dani Muslims in Papua has been associated to social construction of the ethnic and religious aspects as the basis of political policies by the local government. The local government present in the form of Undang-Undang Otonomi Khusus Papua (UU OTSUS Papua) or the Law Number 21 of 2001 concerning Special Autonomy for Papua has been understood to become one of the keys playing roles in constructing the identity of people in modern Papua. This work attempts to review the process of becoming minority of the Dani Muslims within the context of the Papua society. They live in the central mountains with limited infrastructure and access to modern life. The work suggests that the Dani Muslim has become minority in terms of political representation as well as religious identity due to three conditions. First, the practice and implementation of the Law Number 21 of 2001 concerning Special Autonomy for Papua has significantly influenced the live of the Dani Muslims with regards to their political representation as well as religious identity. Second, they embrace Islam as a way of life and have to deal with the cultural conditions of the Dani community in general that are very consistent in maintaining their local tradition. Third, the domination of religious symbols used in public spaces has been found to have much influence to the identity of minority groups. The
\end{abstract}


Christian Papuans later made further claims of Papua as the Land of Christ has had a broad impact not only on the access to public services for the Dani Muslims but has also presented them with new pressure and marginalized in terms of political position and religious group existence.

Keywords: Muslim, politics, religious, minority, representation, identity, Dani, Papua

\section{INTRODUCTION}

When a Muslim indigenous child was born in Papua, at the same time he/ she becomes a minority and a third class citizen. This phenomenon has been understood as the result of the socio-cultural construction and applicable law based on ethnicity and religion. The Dani people who embrace Islam in the Baliem Valley of Jayawijaya represent Muslim indigenous Papuans. Dani Muslims comprise only 1051 people $(0.45 \%)$ of a total of 233,328 inhabitants of Jayawijaya Regency. This minority status is legitimated by Law Number 21 of 2001 concerning Special Autonomy for Papua. This regulation has shaped the community structure into social levels with Papua Christians at the top, Christian migrants in the second, Muslim indigenous Papuans in the third, and Muslim migrants in lowest (Rumbaru, 2019).

The 2010 Population Census statistics show the classification of community groups in Papua. The population of Jayapura City, for example, was divided into indigenous population with 89,773 people (34.97\%) and Non-Papuans with 166,932 people $(65.03 \%)$ from a total of 256,705 inhabitants of Jayapura City (Baharuddin et al., 2016). Referring to the same data, Eben Siadari, an Australian writer, proposed the same claim saying that indigenous Papuans in several major cities of Papua had become the minority. The percentage of the population of non-Papuans is $62.73 \%$ in Merauke, $52.46 \%$ in Nabire, $57.49 \%$ in Mimika, $58.68 \%$ in Keerom, and $65.09 \%$ in the city of Jayapura (Siadari, 2017).

The literature that addresses the minority Muslim community in Papua focuses more on historical studies, religious participation, and education (Wanggai, 2007; Wekke, 2013, 2015, 2018; Murtadlo, 2018) or efforts to spread Islam that have caused opposition in society as a result of the involvement of religious followers who feel they have become the majority (Slama, 2017), with the aim of comparing, negating or refuting claims among religious followers. In contrast to this point of view, this paper seeks to look at how a Muslim community becomes the majority, an issue that receives little attention. The minority status of Papuan Muslims is not only limited to their number, but 
also to the normative legal construction of the state which gains local political legitimacy for three reasons. First, the enactment of Law Number 21 of 2001 concerning Papua's special autonomy has placed Muslims at the bottom of the list of the social strata. Secondly, the claim of birth right of Papuan land in the name of religion has provoked the Christian groups to become the owners of the land. Third, the existence of the domination of religious symbols in public spaces represented by the Christians has contributed to the religious and political dynamics in the region. Those three conditions influencing the status of Muslim minorities in Papua will be the core discussion of this work. This is based on the consideration of whether the minority position has narrowed Muslim access to resources and public services. This unequal position has become a precondition for the very important discussions in the work.

\section{MINORITY MUSLIMS IN ACADEMIC WORKS}

Discussions about Muslim minority groups have been widely reviewed by experts from various parts of the world. Muslim minorities in Western countries are certainly a common topic (Aydin, 2019; Hirsch et al., 2018; Özyürek, 2018; Roach, 2006; Salnikova \& D’Arcus, 2019; Smart-Morstad et al., 2009; Trittler, 2018; Vanparys et al., 2013) with a focus on issues surrounding Islamophobia, immigrant identity, as well as several events regarding terrorism. In addition to Western countries, there is also works that includes the marginalization of Muslims minority in Congo (Leinweber, 2012), Muslim minority groups in Singapore (Roach, 2006), in Nepal (Dastider, 2000), and even Greece (Tsitselikis, 2004) where Muslims as a group have unequal access and treatment in various aspects. Other studies discussed Muslim minority groups in China (Bodde, 1946; Gladney; 1993; Gladney, 2003; Israeli, 1981) and India (Akhtar, 2009; Amin, 2013; Engineer, 2004; Habib et al., 1976; Misra, 2000). In fact, Bodde (1946) mentioned that traditional Chinese people generally are not interested in minority groups so there is no interaction between them and perhaps this has also been one of the triggers of problems today.

In addition, the case of marginalization of Muslim-Rohingya in Myanmar has also been in the spotlight in the literature lately (Alam, 2019; Bashar, 2014; Gunasingham, 2019; Kipgen, 2019). In this conflict, identity is indeed needed for the state to be approved accordingly. For the international community, this identity is important to solve. There are a number of problems where people who want to work on their own or may want to argue in a certain way but must accept an identity that might be compromised so there is tension between groups of people or with the state (Kipgen, 2019). In fact, Muslims are regarded as threat because of their increasing growth in number such as 
the case in Papua New Guinea. Scott Flower (2009; 2012a; 2012b; 2015) looked into the development of Muslims increase which is expected to continue in Papua New Guinea. Because, the transition from the traditional to the modern life that is taking place there, has triggered social and personal crisis which causes people to look for new religions that are closer to the traditional, local, cultural, and material dimensions (Flower, 2015).

In Papua, tensions between minority Muslim groups and local people who embrace Christianity has also been covered in several studies (Aritonang \& Steenbrink, 2008; McGibbon, 2004; IPAC, 2016; Wekke, 2013; Wekke et al., 2018). The Muslim minorities there are not always in a vulnerable position. In the works of Wekke, et al. (2018), the existence of sasi - a typical arrangement of the community for nature protection - is integrated with mosques, both in physical and spiritual forms, so that there is an attachment between the compassion of Muslims and their places of worship. After Islam arrived, this sasi ritual has undergone several changes, for example in the spells, time, and people who lead the rituals. The mosque ultimately has a role to manage and preserve tradition. The conflict that occurred in Papua, between Muslim minorities and indigenous Papuans was Tolikara, which was reported in detail by IPAC (2016). The majority of Muslims is also referred to by Aritonang \& Steenbrink (2008) as immigrants. Papuans then began to indentify Indonesians as those with fair skin, straight hair, and practice Islam. Thus, conflicts between religious groups are more easily ignited.

\section{SPECIAL AUTONOMY LAW AND MINORITY CONSTRUCT IN PAPUA}

Law Number 21 of 2001 concerning the Special Autonomy Law on Papua has in fact produced two frictions in the Papuan community, the indigenous and non-indigenous dichotomy, and two political representations. In fact, the phrase indigenous versus non-indigenous in this law is not explicitly found, but it is implied that the negation of the non-indigenous is obvious. In the consideration section of point (d) in the preamble of the Special Autonomy Law states that "the indigenous population in the Papua Province is one of the groups of the Melanesian race which is part of the nation's ethnic groups in Indonesia, which has its own differences, history, customs, and language. Furthermore, it is emphasized by point (f) that the government has recognized that "the management of wealth of the Papua Province has not been used optimally to improve the living standards of the indigenous Papuans, which has created a gap between the Papua Province and other regions, as well as neglecting the indigenous rights of the indigenous Papuans." 
The crystallization of the concept of indigenous Papuans has increasingly found its form with a specific point that explains who is native in Papua, as stipulated in Chapter I of the General Provisions of Article one (1) point ( $t$ ) which states that indigenous Papuans are people of the Melanesian race consisting of indigenous tribes in the Papua Province and / or people who are accepted and recognized as being indigenous by the indigenous Papuans;" At the same time, in the consideration section, especially point (e) it is stated "that the implementation of governance and development in the Papua Province has not met a sense of justice, has not supported the achievement of people's welfare, has not supported the development of law enforcement, and has not shown respect on Human Rights in the Papua Province, especially for the Papuan society." The use of the word "Papuan Society" at this point seems to provide complete guidance about the Papuan community being fully left behind in various fields, both indigenous and non-indigenous people (as if there were no dichotomy of gap between the peoples of Papua). The dichotomy between indigenous and non-indigenous people as stated in Law No. 21 of 2001 in seen in table 1.

Table 1.

Indigenous and Non-Indigenous Peoples in Papua

\begin{tabular}{|c|c|c|}
\hline Indicator & Criteria & Legitimacy \\
\hline Indigenous & $\begin{array}{l}\text { 1. Race Melanesia, } \\
\text { 2. Native tribes in the Papua } \\
\text { Province } \\
\text { 3. Accepted / accepted by } \\
\text { indigenous peoples }\end{array}$ & $\begin{array}{l}\text { 1. Special Autonomy Law of } \\
\text { Papua } \\
\text { 2. Papuan People's assembly } \\
\text { 3. Customary body }\end{array}$ \\
\hline $\begin{array}{c}\text { Non- } \\
\text { Indigenous }\end{array}$ & $\begin{array}{l}\text { 1. Not a Melanesian race } \\
\text { 2. Not a native tribe in } \\
\text { Papua } \\
\text { 3. Not accepted / recognized } \\
\text { by indigenous peoples }\end{array}$ & $\begin{array}{l}\text { 1. Special Autonomy Law of } \\
\text { Papua } \\
\text { 2. Papuan People's assembly } \\
\text { 3. Customary body }\end{array}$ \\
\hline
\end{tabular}

Another perspective on the existence of minorities regarding the representation of politics which has resulted from the special autonomy law is the filling of the position of Papuan People's Assembly (MRP) members, as well as the elements and leadership of the MRP, where the Muslim community can only place 1 representative out of a total of 51 members in the third period of membership (3), 2017-2022, which can be seen in table 2. 
Table 2

The composition of the MRP members based on religious affiliation

\begin{tabular}{cccc} 
Period & Muslim & $\begin{array}{c}\text { Catholics, } \\
\text { Protestants }\end{array}$ & Total \\
\hline I $(2005-2010)$ & 4 & 38 & 42 \\
\hline II $(2010-2015)$ & 1 & 44 & 45 \\
\hline III $(2017-2022)$ & 1 & 50 & 51 \\
\hline Total & 6 & 132 & 138 \\
\hline
\end{tabular}

Source: processed from primary data and results of interview.

\section{CLAIMS OF PAPUAN LAND BIRTHRIGHT IN THE NAME OF RELIGION}

Indisputably, the claim of birthright of the land of Papua in the name of religion is really happening and even becoming a philosophical basis for the construction of a city. The statements of Ottow and Geisler, which were later used as a marker of Papuan Christianity as the first prayer, became the main foundation for the claims of Papua as the land of Gospel. They declare "in gottes wahen betreten wir das land" (in the name of God we set foot on this land). In another momentum, the affirmation of birthright of Papua in the name of religion gained reinforcement from the statement of I. S. Kijne, an evangelist whose name was enshrined as the name of one of the religious schools in the city of Jayapura. He declared "On this rock I establish the civilization of the people of Papua, even though people have high intelligence, reason and wisdom but cannot lead this nation. This nation will rise up and lead itself.' (I.S Kijne, 25-10-1925)

In a contemporary perspective, the claim of birthright of land in Papua can be seen in the birth of several political policies that accommodate the spirit of religion, such as the appeal of the Mayor of Jayapura about the prohibition on Sunday activities in trade centers. The strict policy which was issued by the Regent of Jayawijaya regulates trading activities on this Sunday through the instruction of the Regent No. 03 of 2013 concerning the prohibition on trading activities on Sundays, as confirmed by the Secretary of Jayawijaya District, Mr Yohanis Walilo to reporters on September 4th 2017:

"We also ordered the leadership of the Civil Service Police Unit to continue patrolling on Sundays. The kiosks can open after four in the afternoon. This is part of giving lesson to the community, because many people don't go to church every Sunday" 
The statement from the Regional Secretary was reinforced by the statement of the Head of Jayawijaya District Civil Service Police Unit, Rustam Haji, as quoted in the Jubi tabloid:

"In accordance with the rules issued by the regional government regarding the prohibition of trading activities on Sundays, there are still many people who conduct trading activities before five in the afternoon, so I hope this (policy) can be obeyed wisely,".

In a broader perspective, the Papua provincial secretary, Mr. Heri Dosinaen on August 18, 2015, also proposed a flight ban on Sundays to get to or leave Papua. He said "We request flight missionaries not to fly on Sundays except in an emergency." In line with the discourse of the Papua Regional Secretary, Liputan 6 reported that 3 regencies, Tolikara, Lani Jaya and Puncak Jaya, have effectively imposed a ban on flights on Sundays to enter their territories. In addition, the use of city slogans with religious enthusiasm is a new trend, such as the slogan of the city of Jayapura that uses local language but with a religious spirit, "Hen tecahi yo onomi tmar ni hanased" which means "one heart (determined) to build a city for the glory of God."

The affirmation of the claims of Papua as a region with certain religious characteristics is increasingly getting its context when observing a number of statements from religious organizations in Papua that require the order, rules and characteristics of the people be based on Christian values. The Indonesian Priests Association along with thousands of people from the Indonesian Christian Communication Forums during the August 4, 2008 staged a demonstration at the office of the Governor of the Papua. The people demands include, among others, refusal to Joint Decree of 5 Ministers in Papua, rejection of Islamic banks, closing of all Islamic boarding schools and Islamic Centers in Buper Waena, and prohibition of the use of Islamic attributes in the public space (headscarves and the like). The demands submitted by FKKI in 2008 were re-submitted by the Association of Jayawijaya Churches in 2016 and the Association of Jayapura Churches (see Image 1), taking the momentum of mosque constructions in Wamena and Sentani. Broadly speaking, these two associations of Christian religious organizations in two different districts voiced the same rejection even in different years with emphasis on rejection of the construction of mosques and prayer rooms even the desire for closure of existing mosques/prayer rooms, prohibition of the use of loudspeakers in mosques, prohibition of the use of Islamic attributes (Muslim clothing), and prohibition of educational facilities and public facilities with Islamic characteristics. 
Image 1

Statement of the Association of Jayawijaya and Jayapura Churches in 2016 and 2018

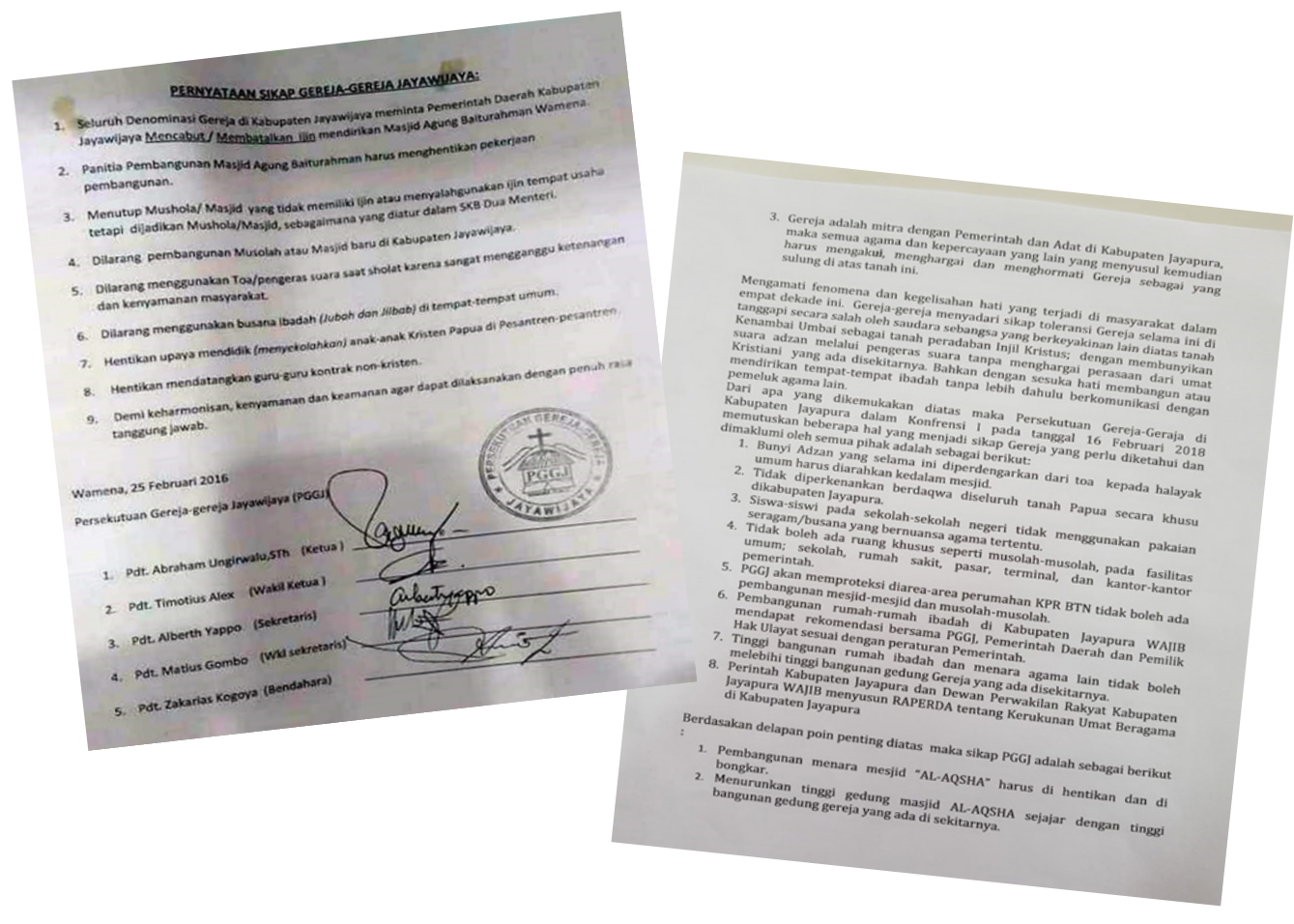

DOMINATION OF RELIGIOUS SYMBOLS IN PUBLIC SPACES

The presence of various religious attributes and markers that were mass displayed in strategic public spaces has become a new agenda in various cities in Papua. It can be directly witnessed that each city must have deliberately created a special space that is not only used as a name marker for a place, but also exudes a strong impression that the city is dominated by the followers of the largest religious group. In the city of Jayapura, public spaces are filled with religious symbols that have become commonplace. The Crucifix Statue that comes with an attractive lighting architecture that emits white light at night, built on a small island in front of the bay of Jayapura, greets travellers visiting the city of Jayapura when using sea transportation. Opposite this island stands the Jayapura Sea port located in a narrow and steeply lined region, which is administratively the district of South Jayapura. The people of Jayapura city refer to this area as the Gadjah Putih Complex. At the top of the cliff above the Gadjah Putih complex, the Jayapura city government places the name of the city of Jayapura icon which is adjacent to the other crucifixion symbols.

At present, the Papua Provincial government is planning to build a new religious symbol in the city of Jayapura, marked by a giant statue of Jesus Christ on the coast of Base G. The Head of the Papua Provincial Public Works 
Office, Mr. Djuli Mambaya, as quoted and reported by BBC Indonesia on the 25th April 2017 stated:

"The 60-meter tall statue is scheduled to be ready by 2020 and part of the IDR 500 billion project includes building a port and access from the capital city of Jayapura to the peak of Mount Swajah. This statue is a symbol of religious diversity, a symbol of the belief of the Papuans ... at the western end there is the Veranda of Mecca and at the east end there is the Canaanite Porch or the Land of Gospel."

Elsewhere, in the Mountain, a Giant Crucifix Monument in Wamena has just been completed which is named Wio Silimo, while in Merauke District, two giant statues of Jesus the Redeemer in Mopah Airport as high as 12 meters and Habe Island as high as 26 have also been erected. In general, almost every city in Papua will surely find religious symbols that are deliberately created and gain legitimacy from the local government. It is interesting to pay attention to the distribution of religious symbol construction, because it will display a unique configuration, which can be seen in the following figure 2 .

\section{Figure 2}

Papua map and configuration of religious symbols

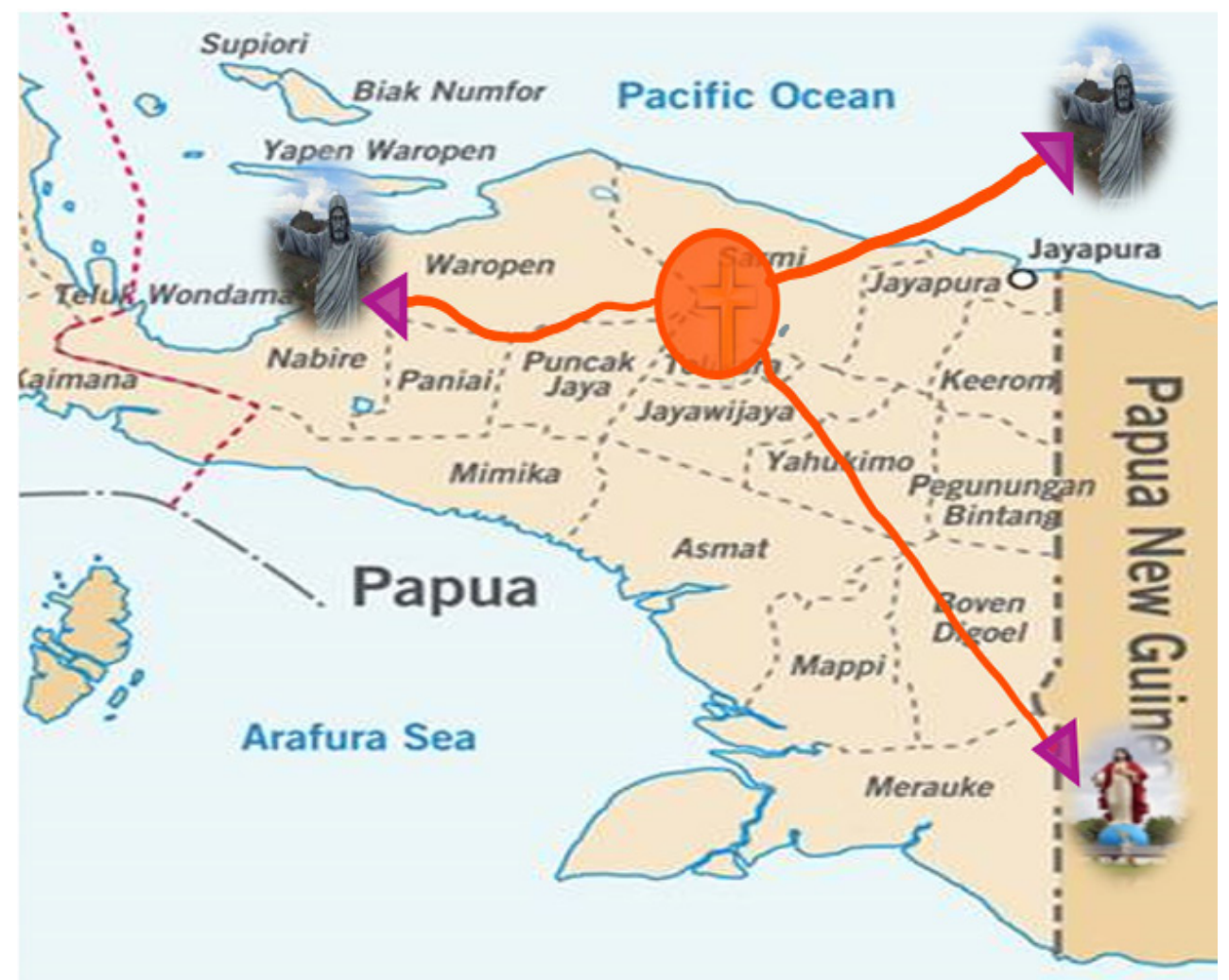




\section{LAW NUMBER 21 OF 2001 AND ITS IMPACT TO PAPUAN MUSLIMS}

In its application, Law Number 21 of 2001 concerning Papua's special autonomy has succeeded in giving birth to a new jargon, "Papuans must be the masters of their own country" and has formed hegemony of thought and understanding of Papuan people in ordinary community groups, politicians, bureaucrats and even among religious leaders. In fact, the jargon does not directly make a particular ethnic group a minority or majority in terms of numbers, but with this term, it can be a shortcut that can create a new reality in understanding the dichotomy between the majority and minority in Papua, especially in terms of controlling resources and access to various kinds of public service facilities. Government programs that have been planned obviously legitimize the dichotomies and classes in society. Unequal rights between indigenous Papuans and non-indigenous people (Non-Papuans) are exhibited massively and supported legal means that apply in a nation state. The division of employment due to ethnicity is clearly stated in open spaces, as a response to point (f) of the preamble of Law on Special Autonomy. Nonnative Papuans are forced to accept the fact that they are of the same position as those who are considered to create disparities so that they are naturally positioned as second-class residents, who at the same time become citizens who receive public services lower than the indigenous Papuans, as a result of efforts to create justice for indigenous Papuans.

The real manifestation of this racial dichotomy is the birth of local and even national government policies that quantify the opportunity to obtain health service facilities, educational opportunities, and employment opportunities and representation models. Consequently, a product of the special Papuan health insurance policy has emerged, an opportunity to continue education in state universities with an allocation of 80:20 as occurred at the Cenderawasih University and the Institute of Public Administration. The recruitment of civil servants and military and police officers is also inseparable from this perspective, with priority being given on the basis of the racial principle, where indigenous people are given a very large portion while the non-Papuan population feel reasonable if they receive a modest portion, and again nonindigenous Papuans are forced to accept a policy model that actually violates their rights as citizens that should be equal in any case. This astonishing inequality can also be seen in the composition of the members of the Papuan People's Assembly of the third term (2017-2022). Based on religion, of the 51 members there is only one Muslim, or in other words only 1 (\%) of the members of the MRP is Muslim, while 99 (\%) is Christian (Protestant and Catholic). 
The construction of the implementation of the Special Autonomy Law for Papua at least indicates three aspects. First, the population dichotomy based on race/ethnicity is a fact and has a direct impact to the opportunity of citizens to obtain public services, where there are favoured and disfavoured parties. Second, systematically being a minority, especially in the event that the opportunity is forced to be accepted by non-Papuans, because it is a legal provision that applies specifically in that area, because in law there is a principle called legal fiction. Third, the legal product made by the state in its implementation is capable of creating a situation of being a minority and the lack of equality of rights between citizens, as occurred in Papua. The consequence of this situation is that the construction of control of resources in the name of race and religion is inevitable which later can be a fertile ground for seedlings of hatred and a growing atmosphere of disharmony between ethnic and interreligious relations.

\section{PAPUA THE LAND OF CHRIST}

The Papuan perspective built on Christian civilization is based on evangelical values by paying attention to the interaction between the zendings and missionaries in the trajectory of the life history of the tribes in Papua that is difficult to ignore. At the same time, the success of the Christians in instilling religious ideology as the basis for social and political movements and culture increasingly found its form, when the era of openness and special autonomy found its way in Papua. The first prayer of Ottow and Geissler on Mansinam Manokwari Beach and the strokes of the I.S. Kijne statement in Wondama Bay are authentic historical evidence of the foundation of the Papuan civilization in the era of enlightenment, and continue to serve as a guide until the current millennial era.

Reproduction of birthright based on Christian values has recently been repeated not only among ordinary people, or religious organizations, but also by the bureaucrats in both the executive and legislative branches by basing arguments on the historical grounds and the special region of Papua where Christianity is the majority embraced by its inhabitants. Such a phenomenon is in fact not surprising since the feeling of being the majority gives rise to euphoria to egotism, and superiority. In other parts of Indonesia, the composition of the population of the majority religion shows the characteristics of government policies and religious leaders who also favour the religion that has the most followers. Aceh and Bali for example, can be used as the main reference to see the practice and expression in the name of a particular religion which is shrouded in a spirit of the majority (Jubba, 2019). 
In several cities in Papua, the spirit of Christianity is paving its way to be legitimized through several regulations issued by local governments, with the main assumption of respecting and giving the majority the opportunity to regulate their territory, which through the rule it is expected that harmony will be created even tend to be controlled. The appeal of the Mayor of Jayapura, the instructions of the District Head of Jayawijaya, or the statement of the Regional Secretary of the Papua Province that placed the reason for making a policy of prohibiting trading activities and airplane flights on Sundays to honor Christian worship days are examples of how religious values are not only able to regulate private life, but also have a very strong contribution to organize and maintain public order, through majority power within government authority. In another perspective, policies in the name of orderliness and safeguarding public interests based on certain religious values have indirectly positioned the community in conditions of compliance not based on legal obedience, but also on the spirit of obedience to the majority.

The situation complies with the majority values above, if examined further, begins with the conditioning of the situation through thought movements on the political platform and religious podiums in closed and private spaces. Gradually the conditioning is then carried out in public spaces, through demonstrative action that tends to be provocative. Rejection of mosque construction, Muslim dress, educational and economic products with Islamic label by several Christian religious groups is an indicator that there is a disturbing feeling of the majority religious group, in the presence of another religion that has the potential not only to occupy and capture the da'wah territory, but also changes the established atmosphere that has already existed and it is feared that it will seize existing resources in the fields of politics, economics, and even changes in life behaviour as a consequence of changing times (Dixon and Berger, 2007).

The description of this section finally shows the emergence of Papuan birthright claims as the land of Gospel (Christ) that has gone through a fairly long and gradual process, involving many situations, and causing endless debate to date. Even so, this dialectical process of religion in the land of Papua enables us to understand three aspects. First, the emergence of the desire of the majority of the people of Papua to convert the island of Papua as the land of Gospel was driven by historical reality and feelings as the majority group. Second, the urge to claim birthright of the land of Papua has been influenced by other realities outside of Papua that display religious practices and models with a feature of partiality in the name of the majority. Third, birthright claims to a region are considered to be an effective way to maintain the existence of 
the majority religion from infiltration of new religions, and can minimize the potential for tension due to encounter of religions that have expansive traits.

\section{DOMINATION OF THE SYMBOL OF RELIGION IN PUBLIC SPACES}

The logical consequence of the existence of a religion is the presence of religious symbols which are not only interpreted as distinguishing identities between religions, they can also be interpreted as an exhibition of the existence and symbol of the greatness and level of civilization of a religion if it is placed in public spaces. In religious symbols filled with artistic values, there are hidden meanings which affirm greatness, virtue, excellence or even power which must therefore be highlighted, mass produced and placed in strategic positions, made as a sign and demarcation that must be obeyed and respected by all concerned parties, in this case other religions that have fewer numbers and limited access to public legitimacy. In Papua, mass production of religious symbols in public spaces continues to occur and gain legitimacy from the power of the government. The various religious symbols that have been erected have cost a lot and funded from the Regional Budget, such as the construction of a Jesus statue in Jayapura which is estimated to cost 500 billion Rupiah. Constructions of the Statue of Jesus Christ in Merauke and the crucifix monument in Wamena were funded by the Regional Budget. It becomes difficult to argue that the emergence of a single religious symbol that has the full support of the regional government is a manifestation of religious hegemony that has received a majority of the spirit of enthusiasm which not only has forced power against followers of other religions who become the majority in one place turned out to be able to infiltrate to the stage of making a political policy and development in an area, even though in the process of making the policy it was always stated that it had been based on applicable rules and procedures.

It appears that the religious spirit of the majority is consciously encouraged to be the main argument of the importance of building religious symbols. The position and location of the construction of the statue of Jesus and the crucifix crosses from the north to the south of the island of Papua, gives a deep image and meaning of hegemony and religious domination enshrined in the form of inscriptions and monuments. The imagination of each person observing these symbolic positions will directly justify what religion is dominant in Papua. The main symbol of Christian identity in the form of monuments was built right in the heart of the island of Papua in Wamena, meanwhile, a gigantic Jesus Christ statues were built evenly in the districts and cities around the island. Finally, the dominance of the symbols of Christianity in Papua whose development 
has been intensively carried out in recent years can show three things. First, the Christian religious symbols built in several cities are an affirmation of the religious identity of the majority group. Second, the majority of religious enthusiasm is able to create hegemony in all aspects of people's lives, including the government which should protect all citizens. Third, the domination of the majority religion is symbolized through the existence of eternal and magnificent inscriptions, as well as the creation of the largest religious image which is strong in the region.

\section{CONCLUSION}

The discussion provided in this work provides a thorough explanation of the various issues being faced by Muslims, especially the Dani Muslims in Papua. The condition of the minority Dani Muslims has placed them in difficult conditions and is faced with two problems at the same time. First, when they embrace Islam as a way of life, they also have to deal with the cultural conditions of the Dani community in general, who are very consistent in maintaining tradition. Second, when they choose Islam, it turns out that their condition is not much different from before. Islam, despite being the majority in Indonesia, is unable to free Dani Muslims from all the problems that surround them. Special Autonomy for Papua is one of the important aspects in the dynamics of the problems faced by the Dani Muslims. Special Autonomy provides vast opportunities for Papuans. However, this does not apply to the Dani Muslims. They are actually trapped in the two forms of situation above. They are at a crossroads between leaving tradition and continuing their belief as Muslims. Special Autonomy which is intended to exclude Papua from various problems has created a new problem for the Dani Muslims. Papuans who have been constructed as "Christians" have become a serious challenge in the midst of the efforts of the Dani Muslims to defend themselves. The Christian Papuans later made further claims of Papua as the Land of Christ. This has had a broad impact not only on the access to public services for the Dani Muslims, but has also presented them with new pressure. In fact, the Dani Muslims are considered to have left their 'destiny' as Papuans despite their physical traits.

In addition, the strengthening of religious identity in Papua has also made the Dani Muslims more creative in facing uncertain conditions. When the Islamic-Christian relation elsewhere heat up, it also affects the Papuans. However, the Dani Muslims do not feel the impact in their environment because they still have strong emotional ties with other Dani communities. Today, Papua has become an arena of identity contestation especially between Islam and Christianity. This has an impact on the relations between the Dani 
Muslims and other Papuans. Therefore, what has been shown in this study at least provides a description of the various problems faced by minority groups, especially in Indonesia.

\section{BIBLIOGRAPHY}

Akhtar, S. (2009). Aligarh Muslim University, A 'Minority Institution' - Agitation, Legislation and The Law Courts, 1965-2009. Proceedings of the Indian History Congress, 70, 1169-1180.

Amin, S. (2013). Educational Status of Muslim Girl Child in Contemporary India: A Case Study of U.P. Proceedings of the Indian History Congress, 74, 993-997.

Aritonang, J.S. \& Steenbrink, K. (2008). Christianity in Papua. Dalam A History of Christianity in Indonesia. Leiden: Brill.

Aydin, Y.N. (2019). Western Liberal Democracy: The Struggle of Muslims for Freedom, Equality, and Dignity. Journal of Muslim Minority Affairs, 39(1), 75-92. DOI: 10.1080/13602004.2019.1589126

Baharuddin, A. et al. (2016) 'Heterogenity of Amber and Komin in Shaping Settlement Pattern of Jayapura City', KOMUNITAS: INTERNATIONAL JOURNAL OF INDONESIAN SOCIETY AND CULTURE. doi: 10.15294/komunitas.v7i2.3287.

Bashar, I. (2014). Myanmar. Counter Terrorist Trends and Analyses, 6(1), 5-6.

Bodde, D. (1946). China's Muslim Minority. Far Eastern Survey, 15(18), 281284.

Dastider, M. (2000). Muslims of Nepal's Terai. Economic and Political Weekly, 35(10), 766-769.

Dixon, J. M. and Berger, P. L. (2007) 'The Sacred Canopy: Elements of a Sociological Theory of Religion', Sociological Analysis. doi: 10.2307/3710433.

Engineer, A.A. (2004). Minorities and Elections: What Are the Options? Economic and Political Weekly, 39(13), 1378-1379.

Flower, S. (2009). The Struggle to Establish Islam in Papua New Guinea (197683). The Journal of Pacific History, 44(3), 241-260.

Flower, S. (2012a). Christian-Muslim Relations in Papua New Guinea. Islam and Christian-Muslim Relations, 23(2), 201-217. DOI: 10.1080/09596410.2012.655541

Flower, S. (2012b). The Growing Muslim Minority Community in Papua New Guinea. Journal of Muslim Minority Affairs, 32(3), 359-371. DOI: 
$10.1080 / 13602004.2012 .727295$

Flower, S. (2015). Conversion to Islam in Papua New Guinea: Preserving Traditional Culture against Modernity's Cargo-Cult Mentality. Nova Religio: The Journal of Alternative and Emergent Religions, 18(4), 55-82.

Gladney, D.C. (1993). The Study of Islam in China: Some Recent Research. Middle East Studies Association Bulletin, 27(1), 23-30.

Gladney, D.C. (2003). Islam in China: Accommodation or Separatism? The China Quarterly, No. 174, 451-467.

Gunasingham, A. (2019). Buddhist Extremism in Sri Lanka and Myanmar: An Examination. Counter Terrorist Trends and Analyses, 11(3), 1-6.

Habib, I., dkk. (1976). Problems of the Muslim Minority in India. Social Scientist, 4(11), 67-72.

Hirsch, M., dkk. (2018). To accept or not to accept: Level of moral concern impacts on tolerance of Muslim minority practices. British Journal of Social Psychology, 58(1), 196-210. DOI: 10.1111/bjso.12284

IPAC. (2016). Rebuilding After Communal Violence: Lessons From Tolikara, Papua. IPAC Report, 29, 1-24.

Israeli, R. (1981). The Muslim Minority in the People's Republic of China. Asian Survey, 21(8), 901-919.

Jubba, Hasse. (2019). Kontestasi Identitas Agama: Spiritual dan Lokalitas di Indonesia. Yogyakarta: ThePhinisi Press-CissRec-UMY.

Leinweber, A.E. (2012). The Muslim Minority of the Democratic Republic of Congo: From Historic Marginalizationand Internal Division to Collective Action. Cahiers d'Études Africaines, 52(206/207), 517-544.

McGibbon, R. (2004). Plural Society in Peril: Migration, Economic Change, and the Papua Conflict. Washington: East-West Center.

Misra, A. (2000). Hindu Nationalism and Muslim Minority Rights in India. International Journal on Minority and Group Rights, 7(1), 1-18.

Murtadlo, M. (2018) 'PERKEMBANGAN PENDIDIKAN MADRASAH DI TANAH PAPUA', Al-Qalam. doi: 10.31969/alq.v21i2.235.

Özyürek, E. (2018). Rethinking empathy: Emotions triggered by the Holocaust among the Muslim-minority in Germany. Anthropological Theory, 18(4), 456-477. DOI: 10.1177/1463499618782369

Roach, K. (2006). National Security, Multiculturalism and Muslim Minorities. Singapore Journal of Legal Studies, 405-438 
Rumbaru, M. (2019) 'THE CONSTRUCTION OF MUSLIM IDENTIY POST SPECIAL AUTONOMY: The Study of Majelis Muslim Papua Existence', Epistemé: Jurnal Pengembangan Ilmu Keislaman. doi: 10.21274/ epis.2018.13.2.339-360..

Salnikova, M. \& D’Arcus, B. (2019). Spaces of Muslim Identity in Inverness, Scotland. Journal of Muslim Minority Affairs, 39(1), 1-12. DOI: $10.1080 / 13602004.2019 .1575022$

Smart-Morstad, K.J., dkk. (2009). CHAPTER TWELVE: Holding Tight With Open Hands-Education at Humlehaveskolen: A Majority Christian Culture and a Minority Muslim Culture Together in a Danish Public School. Dalam Counterpoints Vol 374, The Role of Religion in 21st-Century Public Schools, pp. 203-223. Switzerland: Peter Lang AG.

Siadari, E. N. (2017) Data BPS: Penduduk Asli Jadi Minoritas di 5 Wilayah Papua, SATUHARAPAN.COM.

Slama, M. (2017) 'Papua as an Islamic Frontier: Preaching in "the Jungle" and the Multiplicity of Spatio-Temporal Hierarchisations', From 'StoneAge' to 'Real-Time': Exploring Papuan Temporalities, Mobilities and Religiosities. doi: 10.22459/fsart.04.2015.10.

Trittler, S. (2018). Consequences of religious and secular boundaries among the majority population for perceived discrimination among Muslim minorities in Western Europe. Journal of Ethnic and Migration Studies, 45(7), 1-20. DOI: 10.1080/1369183X.2018.1437343

Tsitselikis, K. (2004). The Legal Status of Islam in Greece. Die Welt des Islams, New Series, 44(3), 402-431.

Vanparys, N., dkk. (2013). The impact of dramatic events on public debate concerning accommodation of Islam in Europe. Ethnicities, 13(2), 209-228.

Wanggai, T. V. (2007) Rekonstruksi Sejarah Islam di Papua. Jakarta: Balibang Kementerian Agama.

Wekke, I. S. (2013) 'MASJID DI PAPUA BARAT : Tinjauan Ekspresi Keberagamaan Minoritas Muslim dalam Arsitektur', El Harakah.

------., (2015) 'ISLAM DI PAPUA BARAT: TRADISI DAN KEBERAGAMAN', ULUL ALBAB Jurnal Studi Islam. doi: 10.18860/ua.v14i2.2652.

, (2018) 'Integrasi Pendidikan Islam dan Pembelajaran Kewirausahaan di Pesantren Minoritas Muslim, FENOMENA. doi: 10.21093/ fj.v9i1.743. 
